\title{
Genotype reaction of Solanum tuberosum, andigena and phureja groups to late blight (Phytophthora infestans Mont. De Bary)
}

\section{Reacción de genotipos Solanum tuberosum grupos andigena y phureja al tizón tardío (Phytophthora infestans Mont. De Bary)}

Jennyfer Moncayo ${ }^{1}$; Roberth Delgado²; Carlos Marcillo² ${ }^{2}$ Claudia Salazar ${ }^{3}$; Carlos Betancourth ${ }^{4}$

\begin{tabular}{l} 
ARTICLE DATA \\
\hline $\begin{array}{l}\text { Estudiante, Ingeniera agrónoma, Universidad } \\
\text { de Nariño, Pasto, Nariño, Colombia, jennyfer. } \\
\text { moncayoo@gmail.com. }\end{array}$ \\
2. Estudiante, Ingeniero agrónomo, Universidad \\
de Nariño, Pasto, Nariño, Colombia, r_jhersson@ \\
hotmail.com.
\end{tabular}

Cite: Moncayo, J., Delgado, R., Marcillo, C., Salazar, C. \& Betancourth, C. (2019). Genotype reaction of Solanum tuberosum, andigena and phureja groups to late blight (Phytophthora infestans Mont. De Bary). Revista de Ciencias Agrícolas. 36 (E): 138-157 doi:https://doi. org/10.22267/rcia.1936E.113

Received: October 92019.

Accepted: November 152019

\begin{abstract}
Potato crop is the fourth main food product in the world, but is affected by Phytophthora infestans, the late blight disease causal agent. This research was carried out in a town of Pasto high plateau, South of Colombia. In order to evaluate the reaction of different genotypes of creole potato (Solanum tuberosum groups Phureja and Andigena) with regard the disease. A Randomized Complete Block design was established with three repetitions, where 30 genotypes were distributed and three plants were evaluated per repetition during two crop cycles in natural exposure to the pathogen. To assess the disease effect on production, the same genotypes were maintained with chemical control in an adjacent batch. Genotypes classified as tolerant are Chaucha Manzana, Cachuda, Criolla Colombia, Malvaseña, Andina and Criolla, during the first cycle with performance values between 23 to 26t.ha-1 and during the second to Calavera Negra, Chaucha Paisa, Ratona, Criolla Galeras, Ratona Roja, Tornilla Roja and Aguacata with performance values between 23 to 28t.ha-1. The graphic severity scale allowed genotypes to be categorized as susceptible and highly susceptible. The results indicate that for the prevalent pathogen race in this study area, there are no resistance sources within the studied collection. However, genotypes such as Criolla Colombia and Andina showed a better performance in terms of yield.
\end{abstract}

Key Words: Genotype, late blight, potato, severity, resistance, race.

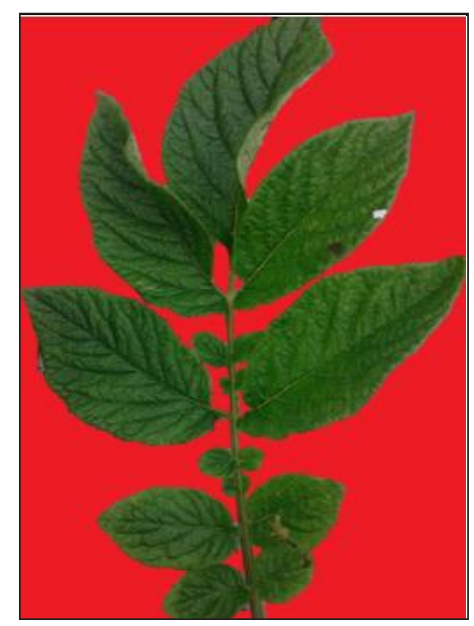

\section{RESUMEN}

RESUMEN

El cultivo de la papa es el cuarto producto principal alimenticio en el mundo, pero es afectado por Phytophthora infestans, agente causante de la enfermedad del Tizón Tardío. La presente investigación se realizó en una localidad del altiplano de Pasto, Sur de Colombia. El objetivo fue evaluar la reacción de diferentes genotipos (Solanum tuberosum grupos phureja y andigena) con respecto a la enfermedad. Se estableció un diseño de Bloques Completos al Azar con tres repeticiones, donde se distribuyeron 30 genotipos y se evaluaron tres plantas por repetición durante dos ciclos de cultivo en exposición natural al patógeno. Para valorar el efecto de la enfermedad sobre la producción, se estableció una parcela con control químico contigua similar a la experimental. Los genotipos clasificados como tolerantes fueron Chaucha Manzana, Cachuda, Criolla Colombia, Malvaseña, Andina y Criolla, durante el primer ciclo con valores de rendimiento entre 23 a 26t.ha- 1 y durante el 
segundo a Calavera Negra, Chaucha Paisa, Ratona, Criolla Galeras, Ratona Roja, Tornilla Roja y Aguacata con valores de rendimiento entre 23 a 28t.ha-1. La escala gráfica de severidad permitió categorizar los genotipos en susceptibles y altamente susceptibles. Los resultados indican que para la raza prevalente del patógeno en esta zona de estudio, no se cuenta con fuentes de resistencia dentro de la colección estudiada, sin embargo se destacan genotipos como Criolla Colombia y Andina, presentaron un mejor comportamiento en cuanto al rendimiento.

Palabras clave: Genotipo, enfermedad, papa, severidad, resistencia, raza.

\section{INTRODUCTION}

Potato (Solanum tuberosum) belongs to the Solanaceae family, originated and domesticated for the first time in the Andes mountains of South America, presenting more than 4,000 varieties of native potatoes, In terms of human consumption it is the fourth most important food crop in the world after rice, corn and wheat (CIP, 2015). According to the CIP in 2015, approximately 1.4 billion people consume potatoes regularly and the total world production of the crop exceeds 300 million metric tons.

In Colombia, the potato crop (Solanum tuberosum L.) generates a large number of rural jobs, by 2017 according to the potato value chain; 264 thousand jobs were generated, of which 75 thousand were direct and about 189 thousand indirect. Nationally about one hundred thousand families are engaged in potato production distributed in 10 departments, although $90 \%$ of the planted area is concentrated in the departments of Cundinamarca (37\%), Boyacá (27\%), Nariño (20\%) and Antioquia (6\%) (SIOC 2019). In the country a wide availability of potato varieties stands out, being the main Pastusa Suprema, Parda Pastusa, Criolla Colombia, Tuquerreña, Sabanera, Única, Rubí and Diacol Capiro which is the most used in the industry (Gómez, 2015).

National production has a $0.5 \%$ share worldwide; however it stands out from other countries because it has a growth rate of
1.35\% (FNFP, 2016). In Colombia, the potato area in 2017 was 128,622 ha, representing a production of 2,701,062 tons and an average yield of 21.0 t.ha-1, with a 3.3\% participation in agricultural GDP, while the participation in Nariño in the same period reports an area of 24,906 ha, with a production of $569,163 t$ and a yield of 21.5 t.ha-1 (SIOC, 2019 ), in addition, the crop has a great socioeconomic importance, because it is one of the fundamental pillars of the departmental economy and from this the income of around 20,000 rural families is derived (ICA, 2018).

In Colombia, the most important disease in potato crops is late blight caused by Phytophthora infestans Mont. De Bary belonging to the Phylum Oomycota (Carreño et al., 2007), which is a hemibiotrophic organism as stated by Nicks and Linhout (2004). It should be mentioned that late blight is a polycyclic disease, that is, it has several cycles of infection and inoculum production during the same season of the crop (Forbes et al., 2014), the main symptoms are brown spots on the leaflets that start from the edges and expand progressively. On the underside, a whitish mycelium is formed that also contains the asexual reproduction structures of the pathogen (sporangia and sporangiophores) (Bustamante, 2015). This disease can present high percentages of incidence and severity in crop areas, becoming epidemic (Silva et al., 2009), and can destroy a crop between 10 to 15 days when control is not appropriate (Bustamante, 2015). In order to maintain the disease level damage below the acceptable 
economic limit, integrated management must be carried out using cultural, biological, genetic and chemical controls (PRIICA, 2017).

For this reason, it is important to make controlled applications of nutrients, especially Nitrogen since it can generate an excess in the foliage when is applied in large quantities, which favors the progress of the disease (PRIICA, 2017), as Juárez et al. (2001) when conducting studies with different genotypes and nitrogen doses, where 33\% ammonium nitrate was used as a nitrogen source: 0.160 and $320 \mathrm{~kg}$.ha- 1 and two moderately resistant genotypes, concluding that the nitrogen increase in folioles it is the most important factor in the development of $P$. infestans and directly affects the resistance components of the plant.

Chemical control is the most used, since it involves the utilization of systemic or contact products capable of preventing infection or performing some type of control after the symptoms onset, in the market there are several chemical groups such as acylalanines, carbamates, dithiocarbamates, acetamides, ptalamides and organophosphates, among others that are used for the management of P. infestans (Pérez and Forbes, 2008). The repeated use of these molecules can lead to pathogen resistance and at the same time increase production costs. According to FEDEPAPA (2017), in Nariño agricultural supplies correspond to $19 \%$ of production costs, highlighting insecticides and fungicides, after fertilizers, amendments and seeds.

Genetic control is also recommended and consists in using the ability of some varieties or plant species to counteract the disease development due to its intrinsic characteristics (Pérez and Forbes, 2008). Therefore, obtaining resistant crops to late blight has been accepted as one of the main strategies to combat the attack of this disease (Juyó et al., 2011) many authors have worked on this subject but has managed to release improved genotypes such as the Pastusa suprema among other released varieties such as Betina and Roja Nariño, a result that was the product of a participatory research process. Consequently, it is considered that resistant, tolerant or susceptible genotypes or intermediate categories can be recognized in plants (Nicks and Linhout, 2004).

On the other hand, the pathogen genetic variability makes vertical resistance not lasting, forcing the use of new products or finding new sources of resistance (Carreño et al., 2007).

With respect to the Solanum genus, the petota section (species that produce tubers) (Spooner and Castillo, 1997) had its center of origin in the Andean zone of South America (Porras, 1999; Rodríguez, 2010), and unlike other crops, the potato presents an extremely large secondary genetic pool, composed by nearby wild species that form small edible tubers (Van den Berg and Jacobs, 2007; Rodríguez, 2010). In the case of Colombia, the two mainly planted species $S$. tuberosum Phureja group known as "criollas" and $S$. tuberosum Andigena group known as "guatas" are the source of this germplasm with utility for genetic improvement.

For the above and as a contribution to the disease management knowledge, in this research the behavior of different potato genotypes was evaluated, regarding the $P$. infestans reaction to explore the presence of resistance sources or disease tolerance. 


\section{MATERIALS AND METHODS}

Location. This research was carried out at the "Guadalupe" farm, in the village of Catambuco, Pasto, Nariño, Colombia, located $9 \mathrm{~km}$ from the city of Pasto, with geographical coordinates $1^{\circ} 09^{\prime} 38.6$ "N and $77^{\circ} 16^{\prime} 57.9^{\prime \prime}$ Or a an altitude of 2,796msnm (POT, 2015), with an average temperature of $13^{\circ} \mathrm{C}$ and an annual rainfall of $967 \mathrm{~mm}$ according to the data obtained from the meteorological station of the Botanical Experimental Farm of the University of Nariño.

Plant material. Genotypes evaluated correspond to the work collection belonging to the Plant Health Research group of the University of Nariño, composed of thirty genotypes collected in different producing areas of the Nariño department. The treatments correspond to the genotypes regionally named by the producers, such as: Aguacata, Andina, Borreguera, Botella roja, Cachona, Cachuda, Calabera negra, Chaucha, Chaucha manzana, Chaucha paisa, Criolla, Criolla Colombia, Criolla galeras, Criolla latina, Curiquinga, Guaneña, Huevo de indio, Malvaseña, Mambera, Ñoña, Punte, Ratona, Ratona amarilla, Ratona negra, Ratona morada, Ratona roja, Tornilla negra, Tornilla roja, Uvilla and Yana shungo.

Area and experimental design. The experimental area corresponded to $1,020 \mathrm{~m} 2$, where three blocks of $5 \mathrm{~m} \times 60 \mathrm{~m}$ were distributed with a separation of one meter between each block.

The experimental design corresponded to Random Complete Blocks with three repetitions, where 30 genotypes were established in experimental units five meters long and two meters wide. The experimental unit corresponded to five rows separated by one meter and with a distance between plants of 0.40 meters. The genotypes were evaluated in field conditions during two production cycles (First cycle: October and January 2017 and Second cycle: March to June 2018) under the influence of the effect of the natural inoculum present in the area, for a total of 2700 plants per experimental unit.

In each test, a land plot equal to the one described above, was used as a reference with chemical control, only for the evaluation of the performance variable.

\section{Response variables}

Incidence. It was calculated as the reference between the number of diseased plants and the total of plants expressed as percentage of the useful land plot of each experimental unit, according to the formula:

$$
\text { Incidence }(\mathrm{I})=\frac{\text { Number of diseased plants }}{\text { Total of plants }} \times 100
$$

Severity. It was evaluated using the modified graphic scale proposed by James Clive (1970) (Figure 1), this scale includes the values: $1,10,25,50,75$ and $100 \%$. The readings were made from the symptoms appearance in plants, with an interval of three to four days. For this, three compound leaves were selected in the three central grooves of each experimental unit, one in the lower third, one in the middle third and one in the upper third, visually evaluating and considering the description presented (Table 1). 


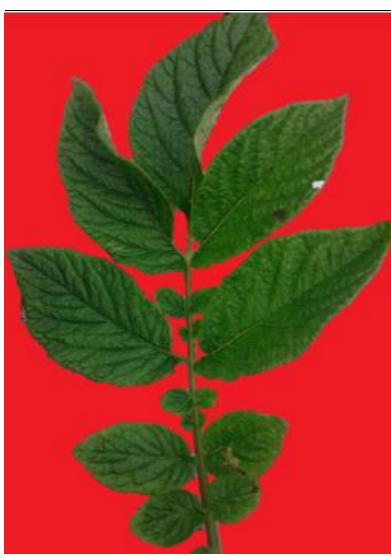

G 0

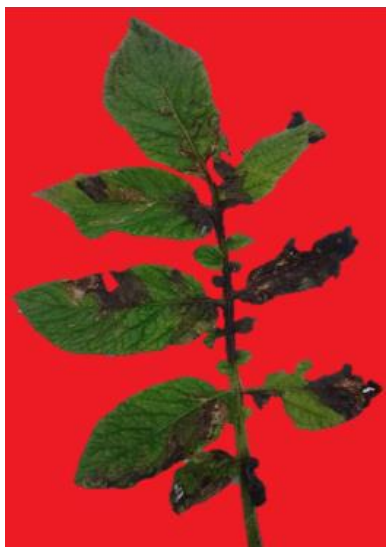

G 3

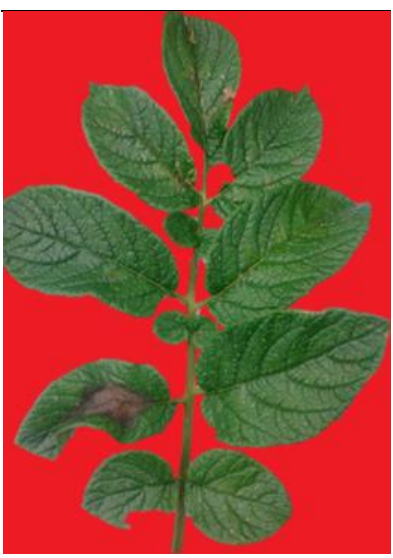

G 1

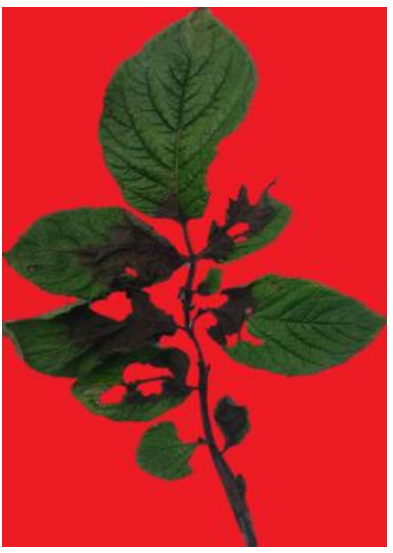

G 4

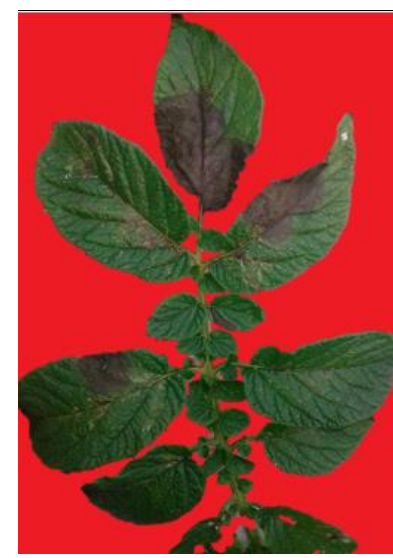

G 2

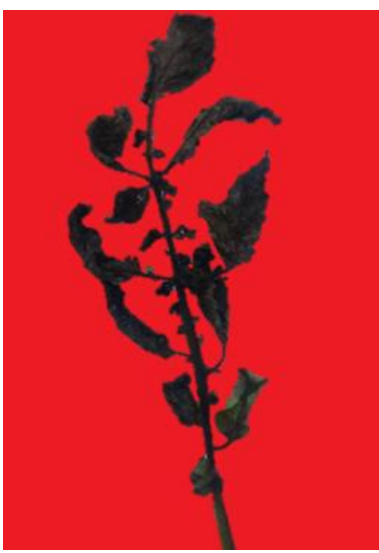

G 5

Figure 1. Graphic scale for severity evaluation of late blight in potatoes (Phytophthora infestans) according to Clive (1970).

Table 1. Graphic scale description in degrees for severity assessment

\begin{tabular}{ccl}
\hline Grade & $\begin{array}{r}\text { Tissue Affected } \\
\text { Percentage (\%) }\end{array}$ & \multicolumn{1}{c}{ Symptoms } \\
\hline 0 & 0 & Late blight not observed \\
1 & $1-9$ & Small necrotic spots on the leaves edges \\
2 & $10-24$ & Necrotic spots approaching leaf veins \\
3 & $25-49$ & Half of the leaflet with brown spots \\
4 & $50-74$ & $\begin{array}{l}\text { Large, brown spots with mycelial tissue on the } \\
\text { underside of the leaf }\end{array}$ \\
5 & $75-100$ & Total dead leaflet \\
\hline
\end{tabular}


Disease development rate. It was calculated applying the equation proposed by Van der Plank (1963) for each genotype.

$$
\mathrm{r}=\frac{1}{t_{f}-t_{i}}\left(\log _{e} \frac{X_{f}}{1-X_{f}}-\log _{e} \frac{X_{i}}{1-X_{i}}\right)
$$

r: Development rate. tf: Final time. ti: Initial time. Loge: Natural logarithm. Xf: Proportion of the disease in the final time. Xi: Proportion of the disease in the initial time.

Area under the disease progress curve (AUDPC). It was calculated from the percentages of the diseased leaf area recorded at different times during the epidemic in both cycles, using the formula proposed by Campbell and Madden (1990) and (Forbes et al., 2014).

$$
\mathrm{AUDPC}=\sum_{i=1}^{n-1}\left(\frac{Y_{i}+Y_{i+1}}{2}\right)\left(t_{i+1}-t_{i}\right.
$$

t: Time of each reading. Y: affected foliage percentage in each reading. $\mathbf{n}$ : Number of readings.

Performance. The production of the useful land plot corresponding to the three central rows of each experimental unit was evaluated and the calculation per hectare was performed. In the same way, the yield value corresponding to the land plot with chemical control was obtained.

Statistical analysis. For the severity variable, genotypes were categorized based on the scale Clive (1977), classifying them from resistant to highly susceptible (Table 2).
Table 2. Graphic scale according to J. Clive (Genotypes classification)

\begin{tabular}{cl}
\hline $\begin{array}{c}\text { Severity in } \\
\text { Percentage } \\
\text { (\%) }\end{array}$ & \multicolumn{1}{c}{ Classification } \\
\hline 100 & Highly susceptible \\
75 & Susceptible \\
50 & Moderately susceptible \\
25 & Moderately resistant \\
10 & Moderately resistant \\
1 & Resistant \\
\hline
\end{tabular}

For the variables of development rate, AUDPC and performance, they underwent an Analysis of Variance under the design model of Randomized Complete Blocks (BCA). For comparison of means differences between genotypes, the Duncan comparison test was used. The values of the variable expressed as a percentage were transformed with the formula ( ).

\section{RESULTS AND DISCUSSION}

Incidence. Most of the genotypes evaluated belonging to $S$. tuberosum Phureja and Andigena groups during the first cycle had a $100 \%$ of incidence, with the exception of Yana Shungo, which showed a $89 \%$ of incidence, while in the second cycle the disease was presented in The totality of the genotypes evaluated reaching $100 \%$ of incidence, reason why it demonstrates that genotypes do not show vertical resistance to $P$. infestans.

According to the proposed by Pérez and Forbes (2008), most of the known genes that provide the characteristic of vertical type resistance to late blight come mainly from S. demissum, as well as some genotypes that share inheritance from wild species $S$. berthaultii and $S$. commersonii, reported by Schilde- 
Rentschler (2003), which have low levels of damage from late blight, This suggests that the disease resistance influences the effect of major genes, and whose expression depends on the virulence variation in $P$. infestans population, present in the corresponding locality (Barquero et al., 2005).

The disease symptoms appearance were similar in the two evaluation cycles, it began after continuous rainfall and relative humidity greater than $70 \%$, where the disease progress is faster and in all genotypes synchronizes this epidemiological phenomenon (Figures 2 and 3 ). The observed results in this study against the onset of the disease were consistent with the data presented by Vaillant and Gómez (2008), who state that after the environmental conditions that favor the incidence of late blight are presented, the disease appears in crops with more than thirty days of age in such a way that if there is no timely control it reaches $100 \%$ of the crop.

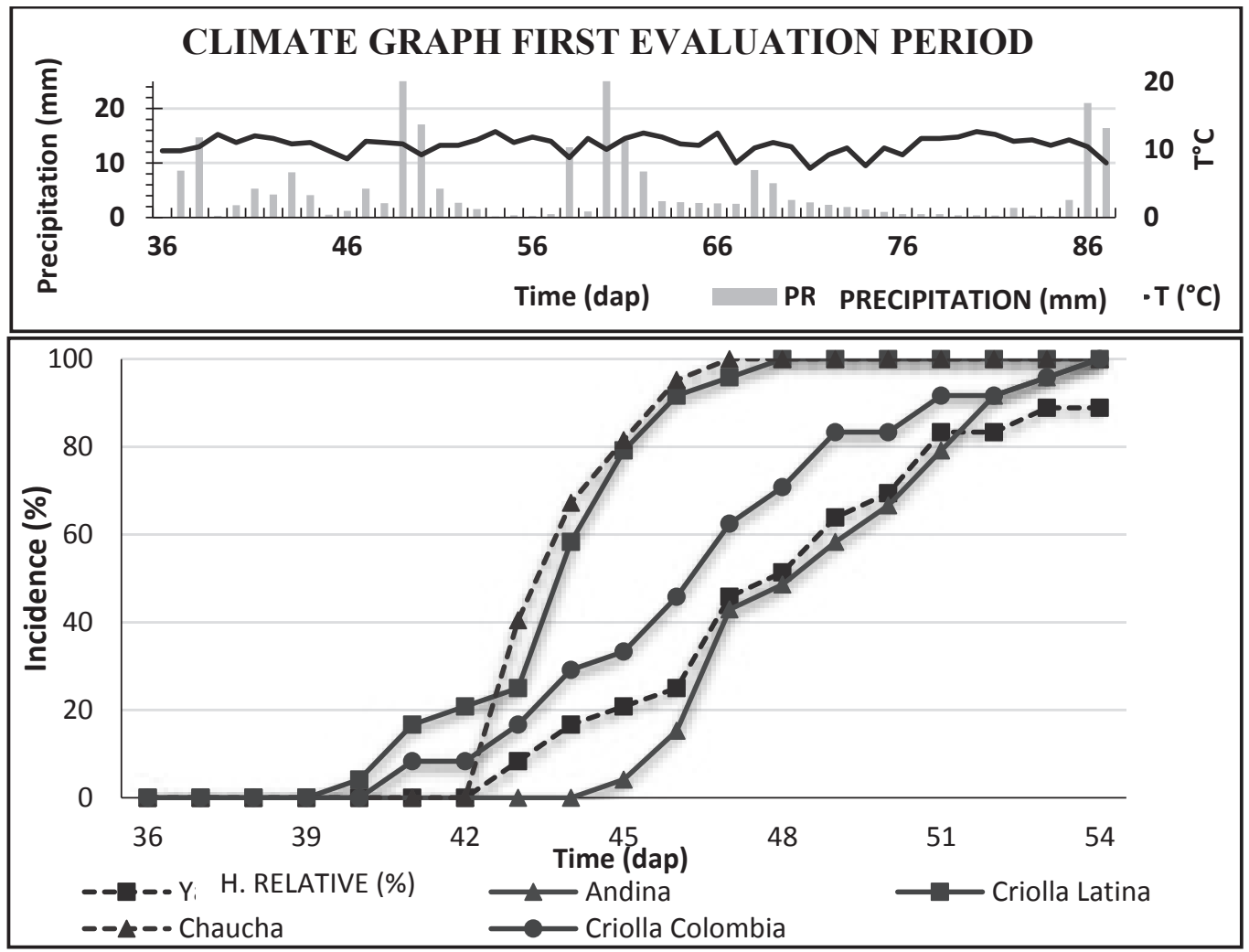

*dap: Days after planting.

Figure 2. Incidence curve of the most representative genotypes during the first cycle, including temperature precipitation temperature. 


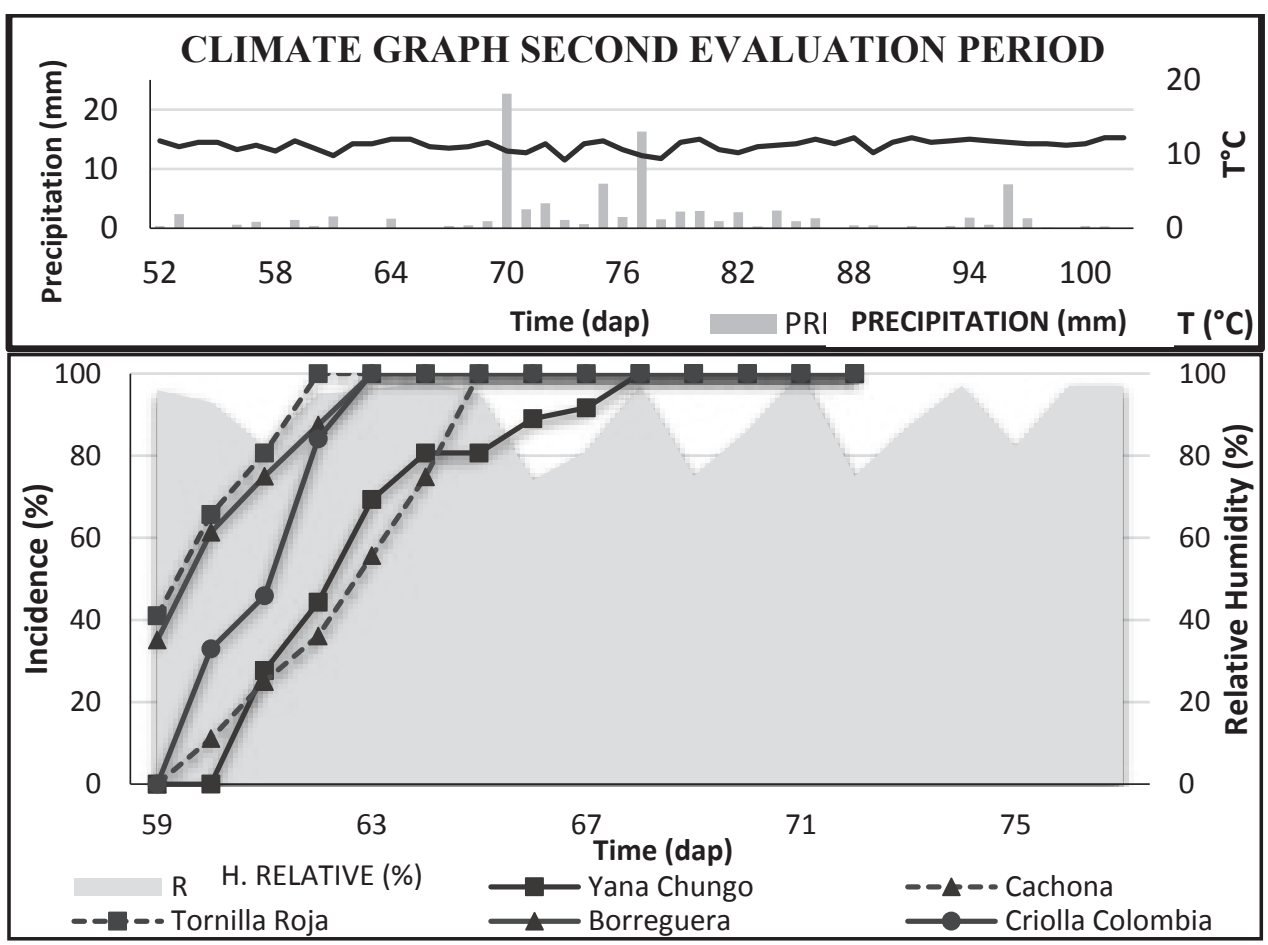

*dap: Days after planting.

Figure 3. Incidence curve of the most representative genotypes during the second cycle, including temperature precipitation temperature.

The incidence in the most representative genotypes such as Yana Shungo and Andina, show fewer symptoms development unlike the Criolla latina, Chaucha and Criolla Colombia genotypes during the first cycle (Figure 2). In the second cycle, Yana Shungo and Cachona stand out again for having a low incidence, while Borreguera and Tornilla roja have a rapid disease symptoms development (Figure 3). In both cycles, the Criolla Colombia genotype is one of the most cultivated genotypes, and being susceptible, it indicates that its incidence reaches 100\% and the incidence curve is in an intermediate range with respect to the total genotypes.

The incidence curve that expresses the disease presence for the two evaluation cycles (Figure 2 and 3), shows that all genotypes are susceptible, possibly due to the different existing races of the pathogen found, as they have expressed in other studies Pérez and Forbes (2017) or the lack of $\mathrm{R}$ genes in the host or compatibility between the host and the host.

S. phureja susceptibility is due to the fact that its reaction against the pathogen is based on minor genes (Landeo, 1997; Rubio et al., 2016), there are genotypes that have lower resistance genes, which indicates that there are an effect on the change of incidence rate among the genotypes evaluated. In addition, it has been proposed that horizontal resistance can be an expression of several genes, including $\mathrm{R}$ gene alleles, that manifest an additional effect on the activation of defense mechanisms (Ghislain et al., 2018; Gebhardt and Valkonen 2001; Rubio et al., 2016). 
Severity. From the disease visual characterization based on James Clive graphic scale, the different genotypes could be classified with respect to their biological reaction against the pathogen, indicating that the majority of genotypes showed a percentage of affection greater than 56\%, being classified as: moderately susceptible to highly susceptible (Table 3). However, during the first cycle, genotypes such as Andina stand out, which have a moderately susceptible reaction, and genotypes such as Cachuda, Aguacata, Borreguera and Ratona Roja categorized as susceptible, reached affection levels between 76 and $83 \%$.

During the second cycle, among the genotypes that have a lower susceptibility reaction and are classified as moderately susceptible, they predominate: Ratona, Ratona Negra and Cachuda, with percentages between 56 and 65\%; and susceptible genotypes such as: Yana Shungo, Tornilla Negra, Andina, Borreguera and Criolla Colombia, whose levels do not exceed $81 \%$, this information can be seen in Table 3.

Table 3. Reaction classification of the Solanum tuberosum group Phureja and Andigena genotypes against P. infestans with regard to Severity, from 39 to 54 dap, during the first cycle and between 59 to 67 dap, during the second cycle.

\begin{tabular}{|c|c|c|c|c|}
\hline \multirow{2}{*}{ Genotype } & \multicolumn{2}{|c|}{ First Cycle } & \multicolumn{2}{|c|}{ Second Cycle } \\
\hline & Severity & Category & Severity & Category \\
\hline Yana Shungo & $84,72 \%$ & A. $S$. & $79,72 \%$ & S. \\
\hline Guaneña & $97,22 \%$ & A. $S$. & $94,44 \%$ & H.S. \\
\hline Malvaseña & $98,61 \%$ & A. $S$. & $88,89 \%$ & H.S. \\
\hline Huevo de Indio & $98,61 \%$ & A. $S$. & $94,44 \%$ & H.S. \\
\hline Curiquinga & $97,22 \%$ & A. $S$. & $97,22 \%$ & H.S. \\
\hline Criolla & $100,00 \%$ & A. $S$. & $98,61 \%$ & H.S. \\
\hline Ratona Amarilla & $84,72 \%$ & A. $S$. & $87,50 \%$ & H.S. \\
\hline Tornilla Negra & $86,11 \%$ & A. $S$. & $81,11 \%$ & S. \\
\hline Cachona & $91,67 \%$ & A. $S$. & $86,11 \%$ & H.S. \\
\hline Andina & $59,44 \%$ & M. S. & $76,78 \%$ & S. \\
\hline Criolla Latina & $95,83 \%$ & A. $S$. & $97,22 \%$ & H.S. \\
\hline Chaucha & $100,00 \%$ & A. $S$. & $100,00 \%$ & H.S. \\
\hline Ratona & $100,00 \%$ & A. $S$. & $56,11 \%$ & M. S. \\
\hline Ñoña & $100,00 \%$ & A. $S$. & $93,06 \%$ & H.S. \\
\hline Criolla Galeras & $98,61 \%$ & A. $S$. & $91,67 \%$ & H.S. \\
\hline Mambera & $100,00 \%$ & A. $S$. & $100,00 \%$ & H.S. \\
\hline Chaucha Paisa & $100,00 \%$ & A. $S$. & $97,22 \%$ & H.S. \\
\hline Chaucha Manzana & $94,44 \%$ & A. $S$. & $84,72 \%$ & H.S. \\
\hline Ratona Negra & $87,50 \%$ & A. $S$. & $65,28 \%$ & M. S. \\
\hline
\end{tabular}




\begin{tabular}{lcccc}
\hline \multirow{2}{*}{\multicolumn{1}{c}{ Genotype }} & \multicolumn{2}{c}{ First Cycle } & \multicolumn{2}{c}{ Second Cycle } \\
\cline { 2 - 5 } & Severity & Category & Severity & Category \\
\hline Uvilla & $98,61 \%$ & A.S. & $95,83 \%$ & H.S. \\
Tornilla Roja & $95,00 \%$ & A.S. & $94,44 \%$ & H.S. \\
Cachuda & $83,33 \%$ & S. & $65,28 \%$ & M.S. \\
Aguacata & $75,00 \%$ & S. & $90,28 \%$ & H.S. \\
Borreguera & $76,39 \%$ & S. & $77,50 \%$ & S. \\
Ratona Morada & $98,61 \%$ & A.S. & $90,28 \%$ & H.S. \\
Calabera Negra & $94,44 \%$ & A.S. & $93,06 \%$ & H.S. \\
Botella Roja & $94,44 \%$ & A.S. & $91,67 \%$ & H.S. \\
Ratona Roja & $81,94 \%$ & S. & $88,89 \%$ & H.S. \\
Punte & $90,28 \%$ & A.S. & $93,06 \%$ & H.S. \\
Criolla Colombia & $90,28 \%$ & A.S. & $81,94 \%$ & S. \\
\hline
\end{tabular}

H.S: Highly susceptible; S: susceptible; M.S: Moderately susceptible.

The graphic severity scale allowed genotypes to be categorized according to their biological reaction to the pathogen, presenting highly susceptible, moderately susceptible and susceptible materials, specified in Table 4.

Table 4. Genotypes reaction of Solanum tuberosum group Phureja and Andigena against $P$. infestans.

\begin{tabular}{|c|c|c|}
\hline Category Severity & Cycle 1 & Cycle 2 \\
\hline $\begin{array}{l}\text { Moderately } \\
\text { susceptible }\end{array}$ & Andina & $\begin{array}{l}\text { Yana Shungo, Ratona, Ratona } \\
\text { Negra, Cachuda }\end{array}$ \\
\hline Susceptible & $\begin{array}{l}\text { Cachuda, Aguacata, } \\
\text { Borreguera, Ratona Roja }\end{array}$ & $\begin{array}{l}\text { Tornilla Negra, Andina, } \\
\text { Borreguera, Criolla Colombia }\end{array}$ \\
\hline $\begin{array}{l}\text { Highly } \\
\text { susceptible }\end{array}$ & $\begin{array}{l}\text { Yana Shungo, Guaneña, Mal- } \\
\text { vaseña, Huevo de Indio, Curiqu- } \\
\text { inga, Criolla, Ratona Amarilla, } \\
\text { Tornilla Negra, Cachona, Crio- } \\
\text { lla Latina, Chaucha, Ratona, } \\
\text { Ñoña, Criolla Galeras, Mam- } \\
\text { bera, Chaucha Paisa, Chaucha } \\
\text { Manzana, Ratona Negra, Uvilla, } \\
\text { Tornilla Roja, Ratona Morada, } \\
\text { Calabera Negra, Botella Roja, } \\
\text { Punte, Criolla Colombia. }\end{array}$ & $\begin{array}{l}\text { Guaneña, Malvaseña, Huevo de } \\
\text { Indio, Curiquinga, Criolla, Ra- } \\
\text { tona Amarilla, Cachona, Criolla } \\
\text { Latina, Chaucha, Ñoña, Criolla } \\
\text { Galeras, Mambera, Chaucha } \\
\text { Paisa, Chaucha Manzana, Uvilla, } \\
\text { Tornilla Roja, Aguacata, Ratona } \\
\text { Morada, Calabera Negra, Botella } \\
\text { Roja, Ratona Roja, Punte }\end{array}$ \\
\hline
\end{tabular}


Considering that the genotypes evaluated showed a similar behavior in the two crop cycles, the severity curves for genotypes with high and low susceptibility were plotted, highlighting during the first cycle:
Chaucha Paisa and Criolla, whose severity degree is higher than the rest and Andina and Borreguera with values of 60 and $80 \%$ respectively, as shown in Figure 4.

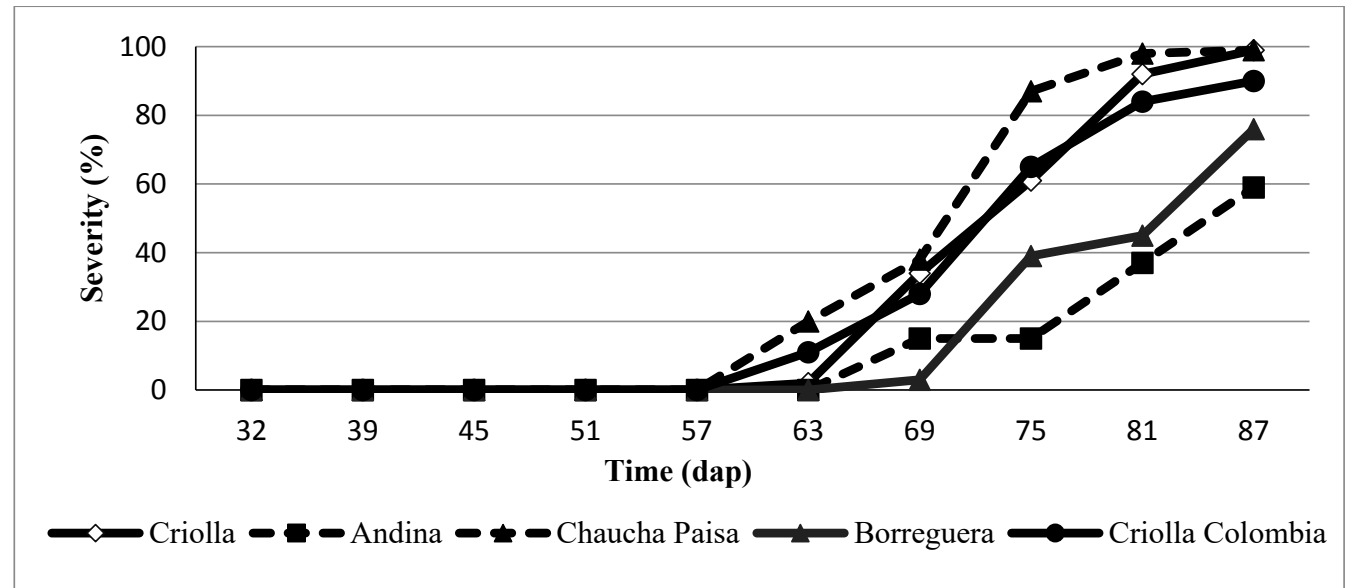

*dap: Days after planting.

Figure 4. Severity curve of a commercial genotype, with the most representative genotypes of the First Cycle.

The two most affected genotypes during the second cycle are: Mambera and Chaucha with a $100 \%$ of severity, while the less affected genotypes are Ratona and Cachuda with 56 and $65 \%$ of severity respectively (Figure 5).

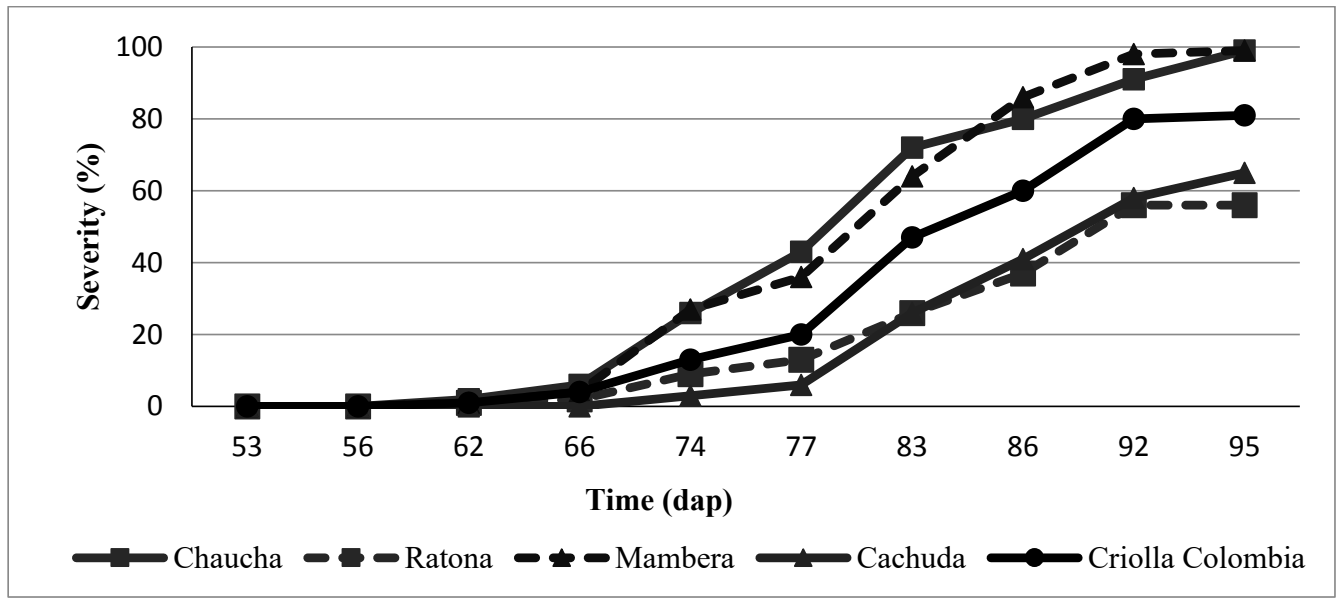

*dap: Days after planting.

Figure 5. Severity curve of a commercial genotype, with the most representative genotypes of the Second Cycle. 
The ideal conditions for the disease development range from temperatures between 15 and $22^{\circ} \mathrm{C}$ and relative humidity greater than $80 \%$ (Cardona-Piedrahita et al., 2016) (Agrios, 2006), which largely coincides with the conditions presented in the two evaluated crop cycles, considering that the disease began to manifest at 56dap, where there was a minimum temperature of $11^{\circ} \mathrm{C}$ that was ideal for germination of the sporangia, and a maximum temperature of $20^{\circ} \mathrm{C}$, in addition a relative humidity of 74 to $89 \%$ during the two crop cycles, and similarly in the second cycle with a humidity in a range of $96-98 \%$, minimum and maximum temperatures of 8 and $18^{\circ} \mathrm{C}$ respectively, these being the higher during this crop cycle and manifested 70 days after planting, in this cycle the conditions favored the disease development in the field.

Additionally, the Ratona genotype during the first cycle was a highly susceptible genotype, reaching $100 \%$ of severity values, while during the second cycle it showed the lowest severity value, so is classified as moderately susceptible genotype (Table 4), having said that during the second evaluation cycle, the development conditions of the disease were not ideal to this patosystem, according to Rivera (2007), if for some reason one of the three elements of the triangle of the disease does not match precisely with others, will not develop.

The Universidad Nacional de Colombia from 2005 to 2007, released the genotypes Gueaneña, Galeras and Criolla Latina, which present a moderate resistance to late blight (Research Group in Potato, 2014), but in this research they showed a highly susceptible behavior, which indicates a resistance rupture observing different severity degrees (Agrios, 2002), something similar happened with Huevo de Indio genotype that despite being resistant to late blight according to the CIP
(2015), was a highly susceptible genotype in both crop cycles.

Research conducted by Mosquera etal.(2008), affirm that some improvement programs have focused on obtaining horizontal resistance varieties, controlled by smaller genes actions, which is more stable and durable than vertical resistance. Identifying eleven resistance genes that come from the wild $S$. demissum species, which induce hypersensitive response (HR) to infection with specific $P$. infestans races (Malcolmson and Black, 1966; Mosquera et al., 2008) However, despite of these gene existence, there is no significant resistance in the present research, considering that all the genotypes evaluated reached high percentages of severity, ensuring the genes absence that confer resistance, new races or more aggressive pathogens.

Development Rate (r). Analysis of Variance shows that the disease development rate was statistically significant $(\mathrm{p} \leq 0.005)$ among the materials evaluated, having a $\mathrm{Pr}>\mathrm{F}$ value of $<, 0001$ and 0.0044 for the first and second cycle.

Comparison of means according to Duncan Table 5 and 6, for first and second cycle, there is a range of susceptibility levels. Largely of genotypes showed high levels of susceptibility, however, the Andina genotype during the first cycle had a growth rate (r) of 0.11 growth units per day, being the lowest of all. The Chaucha paisa genotype is the most susceptible reached a rate $r=0.29$ (Table 5). In the second cycle, genotypes with best behavior were Ratona negra and Ratona with a development rate $r=0.12$ and the most susceptible Criolla latina with $r=0.24$ growth units per day (Table 6). This demonstrates that the environmental conditions and the genetics of the material evaluated allow the pathogen to show its infection potential and increase all epidemiological values of late blight disease on the host. 
Table 5. Comparison of means according Duncan of the disease development rate for genotypes $S$. tuberosum groups Phureja and Andigena. First cycle.

\begin{tabular}{|c|c|c|}
\hline \multicolumn{3}{|c|}{ Cycle 1} \\
\hline Genotype & $\begin{array}{l}\text { Development } \\
\text { rate }\end{array}$ & $\begin{array}{l}\text { Duncan } \\
\text { Grouping }\end{array}$ \\
\hline Chaucha Paisa & 0,29 & $\mathrm{a}$ \\
\hline Guaneña & 0,27 & $a b$ \\
\hline Ñoña & 0,26 & $a b$ \\
\hline Uvilla & 0,26 & $a b c$ \\
\hline Criolla Galeras & 0,26 & abcd \\
\hline Criolla Latina & 0,25 & abcde \\
\hline Chaucha & 0,24 & abcdef \\
\hline Criolla & 0,24 & abcdef \\
\hline Mambera & 0,23 & abcdef \\
\hline Ratona & 0,23 & abcdef \\
\hline Ratona Morada & 0,23 & abcdef \\
\hline Calabera Negra & 0,22 & bcdefg \\
\hline Criolla colombia & 0,21 & bcdefg \\
\hline Aguacata & 0,21 & bcdefg \\
\hline Tornilla Roja & 0,21 & bcdefg \\
\hline $\begin{array}{l}\text { Chaucha } \\
\text { Manzana }\end{array}$ & 0,21 & bcdefg \\
\hline Malvaseña & 0,20 & bcdefg \\
\hline Huevo de Indio & 0,20 & bcdefg \\
\hline Curiquinga & 0,19 & bcdefg \\
\hline Botella Roja & 0,19 & bcdefg \\
\hline Yana Shungo & 0,19 & bcdefg \\
\hline Ratona Amarilla & 0,19 & cdefgh \\
\hline Tornilla Negra & 0,18 & defgh \\
\hline Cachona & 0,18 & efgh \\
\hline Punte & 0,17 & fgh \\
\hline Ratona Roja & 0,17 & fgh \\
\hline Cachuda & 0,17 & fgh \\
\hline Ratona Negra & 0,17 & fgh \\
\hline Borreguera & 0,14 & gh \\
\hline Andina & 0,11 & $\mathrm{~h}$ \\
\hline
\end{tabular}

Table 6. Comparison of means according Duncan of the disease development rate for genotypes $S$. tuberosum groups Phureja and Andigena. Second cycle.

\begin{tabular}{lcl}
\hline \multicolumn{1}{c}{ Genotype } & $\begin{array}{c}\text { Cycle 2 } \\
\text { rate }\end{array}$ & \multicolumn{1}{c}{ Grouping } \\
\hline Criolla latina & 0,24 & a \\
Criolla & 0,21 & ab \\
Chaucha paisa & 0,20 & abc \\
Mambera & 0,20 & abcd \\
Noña & 0,20 & abcd \\
Chaucha & 0,19 & abcde \\
Calabera negra & 0,18 & bcdef \\
Tornilla roja & 0,17 & bcdef \\
Criolla galeras & 0,17 & bcdef \\
Ratona roja & 0,17 & bcdef \\
Curiquinga & 0,17 & bcdef \\
Ratona morada & 0,16 & bcdef \\
Punte & 0,16 & bcdef \\
Uvilla & 0,16 & bcdef \\
Botella roja & 0,16 & bcdef \\
Criolla colombia & 0,15 & bcdef \\
Aguacata & 0,15 & bcdef \\
Chaucha manzana & 0,15 & bcdef \\
Huevo de indio & 0,15 & bcdef \\
Yana shungo & 0,15 & bcdef \\
Malvaseña & 0,14 & cdef \\
Tornilla negra & 0,14 & cdef \\
Andina & 0,14 & cdef \\
Borreguera & 0,14 & cdef \\
Cachona & 0,14 & def \\
Ratona amarilla & 0,13 & def \\
Guaneña & 0,13 & ef \\
Cachuda & 0,13 & ef \\
Ratona negra & 0,12 & f \\
Ratona & f &
\end{tabular}


Ghislain etal. (2018) Affirm that the resistance durability of some genotypes depends on the essentiality of the pathogenicity effector for the pathogen, as well as the pathogen's ability to suppress host immunity, population diversity of the pathogen and how many late blight disease resistance genes are at stake.

In S. phureja genotypes there are minor genes for late blight resistance, which confer different degrees of disease reaction. This condition is important, since, as Estrada and Guzmán (1969) state, it is possible to improve a character controlled by minor genes through a planned combination of its components, through inheritance of horizontal resistance to late blight.

Area under the disease progress curve (AUDPC). The Analysis of Variance showed that the AUDPC was statistically significant (Pr $>\mathrm{F} \leq$ 0.005) among the materials evaluated, having a value of $\mathrm{Pr}>\mathrm{F}$ of 0.0029 and 0.0002 for the first and second cycle.

In the comparison of means according Duncan during both cycles, it shows a wide range of susceptibility levels that can be evidenced in Tables 7 and 8.

During the first cycle, the comparison of means test shows that the Andina genotype presented the lowest value (647.5) of the amount of accumulated disease found throughout the evaluations. While the genotype with the highest value of AUDPC was Ñoña with a value of 2133.3 being the most susceptible (Table 7).

For second cycle of evaluations the genotypes that obtained less disease accumulation throughout the evaluations were Ratona Negra and Cachuda with 649 and 666.1 they presented a similar reaction according to the comparison of means test performed. On the contrary, the most susceptible genotype was Criolla Latina with 1868.9 (Table 8).

The disease expression behavior is due to the plant ability to serve as host and its reaction to the pathogen which depends on its genetic constitution and the interaction between the pathogen and plant tissues (Niks and Linfhout, 2004).

Quantitative resistance, unlike qualitative resistance, is controlled by Quantitative Trait Locus (QTL) or by several genes (Agrios, 2005; Collard et al., 2005) and comprises different reactions that include: penetration rate, restrictions on penetration, restrictions on the rate of invasion of cellular tissue and sporulation rate of the pathogen in the plant. These genes act together for the defense of the plant and the gene performance may be insufficient if it is expressed alone.

Use of R genes against $P$. infestans has been abandoned by plant breeders in favor of the use of quantitative resistance genes. Quantitative resistance opens the possibility of exploring information on the location of positive and negative genetic factors that affect resistance, useful for assisted selection with molecular markers (Collins et al., 1999; Mosquera, 2007).

Performance. Analysis of Variance of Performance in first and second cycle indicate statistical differences between genotypes evaluated presenting a value of $\operatorname{Pr}>\mathrm{F}$ of $<, 0001$ for the first and second. 
Table 7. Comparison of means according Duncan of the AUDPC for genotypes of $S$. tuberosum groups Phureja and Andigena. First cycle.

\begin{tabular}{lrl}
\hline & CYCLE 1 & \\
\hline \multicolumn{1}{c}{ GENOTYPE } & MEDIA & \multicolumn{1}{c}{ DUNCAN } \\
& GROUING \\
\hline Ñona & 2133,3 & a \\
Uvilla & 2094,7 & ab \\
Chacuha Paisa & 2056,7 & abc \\
Criolla Latina & 2046 & abcd \\
Chaucha & 1997,8 & abcd \\
Mambera & 1984,5 & abcd \\
Criolla Galeras & 1869,8 & abcde \\
Criolla & 1755,8 & abcde \\
Chaucha Manzana & 1739,1 & abcde \\
Tornilla Roja & 1719,9 & abcde \\
Ratona & 1707,3 & abcdef \\
Ratona Morada & 1703,3 & abcdef \\
Criolla Colombia & 1633,2 & abcdef \\
Guaneña & 1575,2 & abcdef \\
Aguacata & 1558,7 & abcdef \\
Huevo de indio & 1516,7 & abcdef \\
Calabera & 1499,2 & abcdef \\
Malvaseña & 1498,8 & abcdef \\
Tornilla Negra & 1437,6 & abcdefg \\
Botella Roja & 1425,2 & abcdefg \\
Curiquin & 1407,2 & abcdefg \\
Punte & 1324,1 & abcdefg \\
Ratona Amarilla & 1313 & abcdefg \\
Yana Shungo & 1305,4 & bcdefg \\
Cachuda & 1237,8 & cdefg \\
Cachona & 1230,1 & defg \\
Ratona Negra & efg \\
Ratona Roja & efg \\
Andina & forregue & \\
\hline
\end{tabular}

Table 8. Comparison of means according Duncan of the AUDPC for genotypes of $S$. tuberosum groups Phureja and Andigena. Second cycle.

\begin{tabular}{lrl}
\hline \multicolumn{1}{c}{ GENOTIPO } & MEDIA & \multicolumn{1}{c}{ DUNCAN } \\
& GROUPING \\
\hline Criolla Latina & 1868,9 & a \\
Criolla & 1713,2 & ab \\
Chaucha Paisa & 1633,4 & abc \\
Chaucha & 1617,9 & abc \\
Noña & 1613,8 & abc \\
Mambera & 1596,1 & abcd \\
Calabera negra & 1595 & abcd \\
Ratona Roja & 1394,7 & abcde \\
Criolla Galeras & 1361,6 & abcde \\
Uvilla & 1354 & abcde \\
Punte & 1311,2 & abcdef \\
Botella Roja & 1249,7 & abcdefg \\
Aguacata & 1228,3 & bcdefg \\
Ratona Morada & 1219,7 & bcdefg \\
Tornilla Roja & 1219,3 & bcdefg \\
Curiquinga & 1208,5 & bcdefg \\
Criolla Colombia & 1127,2 & bcdefg \\
Tornilla Negra & 1126,2 & bcdefg \\
Huevo de indio & 1086,8 & bcdefg \\
Yana Shungo & 1057,8 & cdefg \\
Borreguera & 1057,3 & cdefg \\
Chaucha Manzana & 964,8 & defg \\
Ratona Amarilla & 960,6 & defg \\
Andina & 957,6 & defg \\
Guaneña & 935,6 & efg \\
Malvaseña & 903,4 & efg \\
Cachona & 876,5 & efg \\
\hline
\end{tabular}


Using the Duncan comparison of means test (Table 9), the best genotypes were grouped and identified in descending order according to their performance behaviors in uncontrolled disease environments, highlighting genotypes during the first cycle: Chaucha Manzana, Cachuda, Borreguera, Criolla Colombia, Tornilla negra and Cachona that have high yields between 10 and 26.32 t/ha. In the second cycle, Calaverá Negra, Chaucha manzana, Guaneña, Criolla Colombia, Chaucha paisa, Ratona, Criolla Galeras, Ratona Roja, Tornila Roja and Malvaseña stand out for presenting high yields that range between 21 and $28 \mathrm{t} / \mathrm{ha}$.

Table 9: Comparison of means according to Duncan corresponding to diseased plants performance and their respective performance in control treatment.

\begin{tabular}{|c|c|c|c|}
\hline \multicolumn{4}{|c|}{ CYCLE 1} \\
\hline Performance & \multirow[t]{2}{*}{$\begin{array}{l}\text { Duncan } \\
\text { grouping }\end{array}$} & $\begin{array}{l}\text { Performance/ } \\
\text { control }\end{array}$ & \multirow[t]{2}{*}{ Genotype } \\
\hline T/Ha & & T/Ha & \\
\hline Chaucha Manzana & 26,32 & $\mathrm{a}$ & 36,81 \\
\hline Cachuda & 24,44 & $a b$ & 29,58 \\
\hline Borreguera & 23,47 & $a b c$ & 34,10 \\
\hline Criolla Colombia & 21,81 & bcd & 29,44 \\
\hline Tornilla Negra & 20,83 & bcde & 35,56 \\
\hline Cachona & 20,1 & bcdef & 29,24 \\
\hline Malvaseña & 19,9 & cdef & 28,33 \\
\hline Ratona Negra & 19,72 & cdef & 41,74 \\
\hline Calavera Negra & 19,44 & cdef & 36,10 \\
\hline Andina & 18,33 & defg & 26,20 \\
\hline Curiquinga & 18,24 & defg & 26,67 \\
\hline Ratona Amarilla & 17,69 & defgh & 26,25 \\
\hline Guaneña & 16,39 & efghi & 27,78 \\
\hline Ratona Roja & 16,11 & efghi & 28,47 \\
\hline Criolla & 15,7 & fghi & 19,24 \\
\hline Criolla Latina & 15,46 & fghi & 38,75 \\
\hline Aguacata & 15,42 & fghi & 34,10 \\
\hline Mambera & 15,42 & fghi & 23,19 \\
\hline Chaucha Paisa & 13,75 & ghij & 31,89 \\
\hline Huevo de Indio & 13,42 & hij & 30,07 \\
\hline Punte & 12,94 & $\mathrm{ij}$ & 41,94 \\
\hline Tornilla Roja & 11,99 & $\mathrm{ij}$ & 26,81 \\
\hline Uvilla & 11,81 & $\mathrm{ij}$ & 24,44 \\
\hline Ratona & 10,56 & $\mathrm{j}$ & 27,78 \\
\hline Criolla Galeras & 10,48 & $\mathrm{j}$ & 29,93 \\
\hline Ñoña & 10,42 & $\mathrm{j}$ & 22,08 \\
\hline Botella Roja & 9,86 & $\mathrm{j}$ & 18,33 \\
\hline Ratona Morada & 9,86 & $\mathrm{j}$ & 28,06 \\
\hline Criolla & 9,72 & $\mathrm{j}$ & 19,56 \\
\hline Yana Chungo & 1,53 & k & 14,03 \\
\hline
\end{tabular}

\begin{tabular}{|c|c|c|c|}
\hline \multicolumn{4}{|c|}{ CYCLE 2} \\
\hline Performance & \multirow{2}{*}{$\begin{array}{l}\text { Duncan } \\
\text { grouping }\end{array}$} & \multirow{2}{*}{$\begin{array}{c}\begin{array}{c}\text { Performance/ } \\
\text { control }\end{array} \\
\mathrm{T} / \mathrm{Ha}\end{array}$} & \multirow[t]{2}{*}{ Genotype } \\
\hline $\mathrm{T} / \mathrm{Ha}$ & & & \\
\hline Calavera Negra & 28,7 & $\mathrm{a}$ & 35,74 \\
\hline Chaucha Manzana & 25,26 & $\mathrm{ab}$ & 39,44 \\
\hline Guaneña & 24,26 & $a b c$ & 23,89 \\
\hline Criolla Colombia & 23,61 & abcd & 34,44 \\
\hline Chaucha Paisa & 23,14 & abcd & 29,44 \\
\hline Ratona & 23,05 & abcd & 31,30 \\
\hline Criolla Galeras & 22,41 & abcde & 27,59 \\
\hline Ratona Roja & 21,94 & abcde & 26,39 \\
\hline Tornilla Roja & 21,39 & abcdef & 28,98 \\
\hline Malvaseña & 20,33 & abcdef & 35,00 \\
\hline Criolla & 20 & abcdef & 30,22 \\
\hline Curiquinga & 19,72 & abcdef & 31,48 \\
\hline Uvilla & 18,61 & bcdef & 29,82 \\
\hline Andina & 18,33 & bcdef & 27,22 \\
\hline Borreguera & 18,1 & bcdef & 29,44 \\
\hline Ratona Negra & 17,22 & bcdef & 28,75 \\
\hline Mambera & 16,94 & bcdef & 25,28 \\
\hline Ratona Amarilla & 15,74 & bcdefg & 23,89 \\
\hline Aguacata & 15,28 & cdefg & 21,67 \\
\hline Ñoña & 15 & cdefg & 25,94 \\
\hline Cachuda & 15 & cdefg & 22,39 \\
\hline Tornilla Negra & 15 & cdefg & 24,63 \\
\hline Criolla Latina & 14,63 & cdefg & 28,89 \\
\hline Punte & 14,1 & defg & 25,56 \\
\hline Criolla & 13,89 & defg & 26,11 \\
\hline Cachona & 13,29 & efgh & 28,30 \\
\hline Ratona Morada & 12,22 & fgh & 37,22 \\
\hline Botella Roja & 6,67 & gh & 19,72 \\
\hline Huevo de Indio & 4,81 & $\mathrm{~h}$ & 15,56 \\
\hline Yana Chungo & 4,63 & $\mathrm{~h}$ & 11,94 \\
\hline
\end{tabular}


The evaluations carried out in the two crop cycles, affirm that the disease manifested between 50 and 60 dap, shown in the tables of both incidence and severity and at the same time in Table 9, which reflects the existing differences between the control performance and the control, demonstrating that the disease development not only influenced the physiologically active foliage duration but also had an impact on the obtained yield (Wagoner and Berger, 1987; Montes et al., 2011). Since the disease development affects tuberization, one of the most important events in the crop (Sands et al., 1979; Kooman and Haverkort, 1995; Morales et al., 2011), and directly affecting the productive stage which occurs in early varieties at 30 days and in intermediate varieties between 35 and 45 days (INTA, 2004).

Results of earlier researches such as Lozoya and Hernández (2001), state that by presenting genotypes with severity greater than 35\%, the yield is considerably reduced, which coincides with the results obtained in the present research since affectation levels were presented over $56 \%$.

Consequently, Yepéz (2016), states that the decrease in the leaf area caused by the disease influences the decrease in performance, however, according to the disease epidemiological evaluation and based on performance, tolerant genotypes are evidenced, and despite presenting the disease, they did not have significant decrease in their performance when compared to the control, this phenomenon showed a polygenic resistance in the genotypes where the pathogen developed widely reaching high severity values, but finally the plant reached high yields.

Evidently, the disease development significantly influences performance, and for this reason it is important to continue the research and use new verification methods, such as other researches carried out where they consider that using the
AUDPC as a response variable being this a good approximation to determine the type of reaction, which according to Portilla and Salas (2007), is an important source of information to obtain potentially productive and disease tolerant materials.

\section{CONCLUSIONS}

The genotypes evaluation of Solanum tuberosum group Phureja and Andigena focused on the reaction against the late blight disease presence ( $P$. infestans), which did not present resistance of vertical type but it is possible to highlight the existence of tolerant materials such as: Criolla, Criolla Colombia, Chaucha Paisa, Andina, Ratona Roja and Guaneña, which, despite having severity and incidence high percentages, showed a better performance.

Through evaluations of the epidemiological variables and performance, tolerant materials that can serve as a genetic alternative to counteract the effect of the pathogen were observed and used as an option for genetic improvement.

\section{ACKNOWLEDGEMENTS}

Vicerrectoría de Postgrados y Relaciones Internacionales -VIPRI- de la Universidad de Nariño y al grupo de investigación Sanidad Vegetal -GRISAV- de la facultad de Ciencias Agrícolas.

Conflict of interest: The authors declare that there is no conflict of interest.

\section{BIBLIOGRAPHIC REFERENCES}

Agrios, G. (2005). Fitopatología. Segunda Edición. México: Limusa. 838 p. 
Agrios, G. (2006). Plant Pathology. Tercera Edición. México: Limusa.

Barquero, M., Gómez, L. \& Brenes, A. (2005). Resistencia al tizón tardío (Phytophthora Infestans) en clones promisorios de papa en Costa Rica. Agronomía Costarricense. 29(3): 3145 .

Bustamante, G. (2015). Control biológico del Tizón Tardío Phytophthora infestans en papa Solanum tuberosum a través de consorcio microbiano formado por hongos nativos del género Trychoderma sp. recovered from https://dspace. ups.edu.ec/bitstream/123456789/7692/1/ UPS-CT004553.pdf

Campbell, C. \& Madden. L. (1990). Introduction to plant disease epidemiology. New York: John Wiley. 532p.

Cardona-Piedrahita, L. F., Castaño-Zapata, J., \& Ceballos-Aguirre, N. (2016). Epidemiología del tizón tardío (Phytophthora infestans Mont. de Bary) en quince introducciones del tomate silvestre. Revista UDCA Actualidad \& Divulgación Científica. 19(1): 45-54.

Carreño, N., Vargas, A., Bernal, J. \& Restrepo, S. (2007). Problemas fitopatológicos en especies de la familia Solanaceae causados por los géneros Phytophthora, Alternaria y Ralstonia en Colombia. Agronomía Colombiana. 25(2). 320329.

CIP - International Potato Center (2015). Datos y cifras de la papa. recovered from https:// cipotato.org/es/lapapa/dato-y-cifras-de-lapapa/

Clive, J. (1977). A manual of disease assessment keys for plant diseases. Canada: Department of Agriculture. 50 p.

Estrada, N. \& Guzmán, J. (1969). Herencia de la resistencia de campo a Phytophthora infestans (tizón) en variedades cultivadas de papa (tuberosa y andigena). Revista Ica. 4(3):117138.

FEDEPAPA - Federación Colombiana de Productores de Papa. (2017). Expectativas y anhelos del sector productivo de cultivadores de papa a partir del año 2017. Edición No. 40. Bogotá: FEDEPAPA. 52p.

FNFP - Fondo Nacional de Fomento de la Papa. (2016). Informe de gestión. Recovered from https://fedepapa.com/wp-content/ u p l o a d s / 2017 / 01 / I N F O R M E - D E GESTIO\%CC\%81N-FNFP-ANUAL-2016.pdf

Forbes, G., Perez, W. \& Andrade, J. (2014). Procedimiento para evaluación estándar y manejo de datos de clones avanzados de papa. Módulo 3: Evaluación de la resistencia en genotipos de papa a Phytophthora infestans bajo condiciones de campo. Guía para colaboradores internacionales. Perú: Centro internacional de la papa-CIP. 50p.

Gebhardt, C. \& Valkonen, J. (2001). Organization of genes controlling disease resistance in the potato genome. Ann. Rev. Phytopathol. 398(1): 79-102.

Ghislain, M., Arinaitwe, A., Byarugaba, E., Njoroge, A., Rivera, C., Roman, M., Tovar, J., Gamboa, S., Forbes, G., Kreuze, J., Barekye, A. \& Kiggundu, A. (2018). Stacking three late blight resistance genes from wild species directly into African highland potato varieties confers complete field resistance to local blight races. Plant Biotechnology Journal. 17(6): 1119 - 11129p. doi: $10.1111 / \mathrm{pbi} .13042$

Gómez, L. (2015). Contexto ganadero: Asi es el mundo de la papa colombiana. Recovered from https://www.contextoganadero.com/ agricultura/informe-asi-es-el-mundo-de-lapapa-colombiana

Grupo de investigación en papa. (2014). Criolla Guaneña. Recovered from http://www. papaunc.com/catalogo/criolla-guanena

ICA- Instituto Colombiano Agropecuario. (2018). El ICA realiza inspección y vigilancia fitosanitaria a cultivos de papa en Nariño. Recovered from https://www.ica.gov.co/noticias/ica-inspeccion-vigilancia-cultivo-papa

INTA - Instituto Nicaraguense de Tecnología Agropecuria (2004). Manejo Integrado de Plagas: Cultivo de papa. Instituto Nicaraguense de Tecnología Agropecuria. Primera Edición. Managua: INTA. 
Juárez, H., Amaro, J., Rivera, M., Párraga, A. \& Hijmans, R. (2001). Effect of nitrogen on potato late blight. Recovered from https://research.cip.cgiar.org/confluence/ download/attachments/37192024/7_Effect_ nitrogen_.pdf?version $=1 \&$ modification $\mathrm{Da}$ te $=1273689363000$

Juyó, D., Gerena, H. \& Mosquera, T. (2011). Evaluación de marcadores moleculares asociados con resistencia a gota (Phytophthora insfestans L.) en papas diploides y tetraploides. Revista Colombiana de Biotecnologia. 13(2): 5162.

Kooman P.L. \& Haverkort A.J. (1995) Modelling development and growth of the potato crop influenced by temperature and daylength: LINTUL-POTATO. In: Haverkort A.J., MacKerron D.K.L. (eds) Potato Ecology And modelling of crops under conditions limiting growth. Current Issues in Production Ecology. Vol 3. Dordrecht: Springer.

Landeo, J. (1997). Strategies on breeding for resistance to late blight in potato at CIP. México: INIFAP.

Lozoya, H. \& Hernández, A. (2001). Registered and section 18 compounds for control of late blight (Phytophthora infestans Mont. De By) in potatoes in Toluca, Mexico. Agrociencia. 35(4): 451-458.

Malcolmson, J. \& Black, W. (1966). New R genes in $S$. demissum Lindl. and their complementary races of Phytophthora infestans (Mont.) de Bary. Euphytica, 15: 199-203.

Montes, G., Lozoya, H. \& Hernández, A. (2011). Adaptación por resistencia al tizón tardío (Phytophthora infestans Mont. De By) de genotipos de papa (Solanum tuberosum L.) en Toluca, México. Rev. Chapingo S. Hort. 9: 193208.

Morales, S., Mora, R., Rodríguez, J., Salinas, M., Colinas, M. \& Lozoya, H. (2011). Desarrollo y rendimiento de papa en respuesta a la siembra de semilla-tubérculo inmadura. Revista Chapingo. Serie horticultura. 17(1): 67-75.
Mosquera, T., Fernández, C., Martínez, L., Acuña A. \& Cuellar, D. (2008). Genética de la resistencia de la papa (S. tuberosum) a patógenos. Agronomía Colombiana: 26(1): 7-15.

Nicks, R, E. \& Lindhou, W, H. (2004). Curso sobre mejoramiento para resistencia durable a patógenos especializados. Tercera Edición. Quito, Ecuador: Wageningen Agricultural University, The Netherlands.

Peréz, W. \& Forbes, G. (2008). Manual técnico: El tizón tardío de la papa. Centro Internacional de la Papa (CIP). Lima: Comercial Grafica Sucre. 39p.

Peréz, W. \& Forbes, G. (2017). Manejo integrado del tizón tardío: ¿Qué es la resistencia genética?. Perú, Lima: CIP, Centro Internacional de la Papa. $4 \mathrm{p}$.

Porras, P. (1999). La papa en Colombia: Desarrollo de una cadena agroalimentaria estratégica. Revista FEDEPAPA. 3: 14-17.

POT- Plan de Ordenamiento Territorial. (2015). POT Pasto territorio con sentido. 2014-2027. Alcaldía de Pasto. Secretaria de planeación. 2015. Recovered from https: / / www.pasto.gov.co/index.php / component/phocadownload/category/315planeacion -2015 ?download $=6756$ : cartilla pot_2014_2027_v1

PRIICA - Programa Regional de Investigación e Innovación por Cadenas de Valor Agrícola. (2017). Manejo de la enfermedad "tizón tardío" (Phytophthora infestans) de la papa. Presentación de resultados del Programa Regional de Investigación e Innovación por Cadenas de Valor Agrícola en Honduras. Recovered from http://repiica.iica.int/docs/ B4175e/B4175e.pdf.

Rivera, G. (2007). Conceptos Introductorios a la Fitopatología. Primera Reimpresión de la Primera Edición. Costa Rica: San José. Editorial: Universidad Estatal a Distancia (EUNED). 346 p.

Rodríguez, L., (2010). Origen y evolución de la papa cultivada. Una revisión. Agronomía Colombiana. 28(1): 9-17. 
Rubio, O., Cadena, M. \& Flores, R. (2016). Comparación de la resistencia horizontal y vertical contra el tizón tardío de la papa en Toluca. Revista mexicana de ciencias agrícolas. 7(4): 755-766.

Sands, P., Hacket, C. \& Nix, H. (1979). A model for the development and bulking of potatoes (Solanum Tuberosum L.) I. Derivation from wellmanaged field crops. Field Crops Research. 2: 309-331.

Schilde-Rentschler L. (2003). Focus on partners: The INCO-PAPA Project. Recovered from http:// cipotato.org/wp-content/uploads/2014/07/ GILB_news_-20.pdf

Silva, B., Jaramillo, S. \& Marin M. (2009). Caracterización genética de aislamientos de Phytophthora infestans en las zonas productoras de papa de los departamentos de Antioquia, Boyacá, Cundinamarca y Norte de Santander (COLOMBIA). Actualidades Biológicas. 31(90): 5-20

SIOC - Sistema de información de Gestión y Desempeño de Organizaciones de Cadenas. (2019). Cadena de papa: Indicadores e Instrumentos. MinAgricultura. Colombia. Recovered from https://sioc.minagricultura. gov.co/Papa/Documentos/2019-12-11\%20 Cifras\%20Sectoriales.pdf

Spooner DM, Castillo R. 1997. Reexamination of series relationships of South American wild potatoes (Solanaceae: 75 Solanum sect. Petota): evidence from chloroplast DNA restriction site variation. Amer. J. Bot. 84: 671-685

Vaillant, D. \& Gómez, G. (2008). Incidencia de Phytophthora nicotianae y Phytophthora infestans en Cuba. Agricultura técnica en México. 35(2): 219-223.

Van den Berg, R.G. \& Jacobs, M.J. 2007. Molecular taxonomy. In: Vreugdenhil, D. Potato biology and biotechnology advances and perspectives. pp. 55-74. Amsterdam: Elsevier. 856p.

Van der Plank, J. (1963). Plant diseases. Epidemics and control. New York: Academic Press. 349p.
Waggoner, P. \& Berger, R. (1987). Defoliation, disease, and growth. Phytopathology. 77: 393398.

Yepéz, L. (2016). Validación de estrategias de manejo del tizón tardío (Phytophthora infestans) de la papa en tres variedades, Pillaro. Quito: UCE. 73 p. Recovered from http://www. dspace.uce.edu.ec/handle/25000/8223 